Agro-Science Journal of Tropical Agriculture, Food, Environment and Extension Volume 9 Number 3 September 2010 pp. $147-153$

ISSN1119-7455

\title{
SOYBEAN CONTRIBUTION TO NUTRIENT BALANCE IN A CASSAVA (Manihot esculenta Crantz) BASED CROPPING SYSTEM.
}

\author{
Umeh, S.I and Mbah, B.N. \\ Department . of Crop Science, University of Nigeria Nsukka, Nigeria.
}

\begin{abstract}
The effects of varying levels of applied fertilizer and nutrient contribution of soybean on soil nutrient nitrogen and potassium ( $N$ and $K$ ) balance in a cassava/soybean intercrop system was studied at Nsukka in a derived Savannah location of South Eastern Nigeria. Two varieties of cassava and six varieties of soybean of three maturity groups were grown as sole and intercrop with four rates of $N$ and $K$ fertilizer. Four input and four output processes were used to quantify the partial nutrient balance of the system. The results showed that sole cassava had negative $N$ and $K$ balances at $N_{0} K_{0}$ and $N_{45} K_{0}$ fertilizer rates and positive balance at only $N_{45} K_{50}$ fertilizer rate. Application of $N_{0} K_{50}$ fertilizer rate gave the highest positive $N$ and $K$ balances. Intercropping cassava (NR 8230) with medium maturing variety of soybean, (TGX 1894-3E) gave the highest $N$

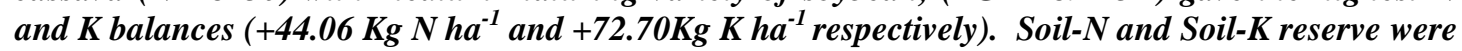
highest at TGX 1894-3E by $N_{0} K_{50}$, Addition of soybean residue into the intercropping system improved soil nutrient status and resulted in positive nutrient balance. Cropping cassava without soybean residue management and starter nitrogen $\left(N_{0} K_{0}\right)$ led to negative nutrient balance $(-27 \mathrm{Kg} N$ $\left.h a^{-1}\right)$.
\end{abstract}

Key words; partial nutrient balance, intercrop, Nitrogen fixation, cassava, soybean.

\section{INTRODUCTION}

Nutrient budgets (input and output balances) are used as indicators for the sustainability of land use system (Dechert et al., 2004). By using nutrient budget analysis, agricultural production systems which are not sustainable, either because of nutrient depletion, leaching or volatilization are identified. Nutrient balance quantifies the flow of nutrient in and out of the farming system. According to FAO (2003), agricultural intensification without adequate restoration of soil fertility threatens sustainability of agriculture. The challenge is to preserve land against nutrient depletion and to make it productive. Loss of soil nutrients a serious threat to sustainable crop production (Van der Pol and Traore, 1993) With the prevailing farming system in the derived Savannah zone, yields are bound to drop because of continuous nutrient mining through crop yield without adequate replenishment from crop cycle to crop cycle. Excessive use of chemical fertilizers results in high soil acidity and increased land degradation (Ladha and Reddy, 2003) Intercropping with soybean and utilizing the crop residue plays important role in improving nitrogen economy (Umeh, 2002).

Ledgard (2001), noted that intercropping promises sustainable plant production. Aggarwal et al. (2002) suggested that selecting and integrating legumes into various production systems should maintain a non-declining mineral trend from crop cycle to crop cycle and that the rate of replaced nutrient within or between cropping cycles must at least equal the rate of removable during the previous cropping. The objectives of this research therefore, were to select soybean variety most beneficial for cassava production and determine the combined effects of applied fertilizer $(\mathrm{N}$ and $\mathrm{K})$ and soybean nitrogen fixation on the $\mathrm{N}$ and $\mathrm{K}$ balances of the intercrop system.

\section{MATERIALS AND METHODS}

The experiment was conducted at University of Nigeria, Nsukka farm which is located at latitude $06^{0} 52$ ' $\mathrm{N}$ and longitude $07^{\circ} 24^{\prime \prime} \mathrm{E}$ and at $447 \mathrm{~m}$ above the sea level, between August 2004 and July 2005. Experimental design used was split plot in randomised complete block design, having two factors; fertilizer rates and cropping systems. Six varieties of soybean of three maturity classes (early, medium and late maturing) were intercropped with two varieties of cassava. Four fertilizer rates were randomised in the main plot, while twenty cropping systems comprising six sole soybean, two sole cassava and twelve cassava/soybean intercrop were randomised in the sub- plots. 
Cassava varieties used were TMS 30572 and NR 8230.The six varieties of soybean used were TGX 1448-2E and Samsoy-2,(early maturing varieties), TGX 1894-3E and TGX 180531F,(medium maturing varieties),'TGX 1889-12F and TGX 1864-17F, used (late maturing varieties). The four fertilizer rates were: $\mathrm{N}_{0} \mathrm{~K}_{0}, \mathrm{~N}_{0} \mathrm{~K}_{50}, \mathrm{~N}_{45} \mathrm{~K}_{0}$ and $\mathrm{N}_{45} \mathrm{~K}_{50} \mathrm{Kg} \mathrm{ha}^{-1}$, where $\mathrm{N}$ and $\mathrm{K}$ were nitrogen and potassium respectively, subscripts 0,45 and 50 were levels of $\mathrm{N}$ and $\mathrm{K} \mathrm{Kg} \mathrm{ha}{ }^{-1}$ respectively. The nitrogen source was Urea and potassium source was muriate of potash. A uniform application of $30 \mathrm{Kg}$ $\mathrm{ha}^{-1}$ of $\mathrm{P}$ as single supper phosphate was applied to all plots.

Plot size was $4.0 \mathrm{~m} \mathrm{X} 3.0 \mathrm{~m}$., containing 4 ridges at $1.0 \mathrm{~m}$ spacing. Soybean was planted on both sides of the ridge at a plant distance of $10.0 \mathrm{~cm}$ while cassava was planted at a plant distance of $0.75 \mathrm{~m}$ on the crest of the ridges. Both cassava cuttings (20 cm long) and soybean seeds were planted at the same time. Cassava plant population was $13,333.33$ plants $\mathrm{ha}^{-1}$ while soybean was thinned down to plant population of 200,000 plants $\mathrm{ha}^{-1}$. Soil samples at $0-30,30-60$ and $60-90 \mathrm{~cm}$. depths were taken before treatment application at the beginning of experiment, at harvest of soybean and at harvest of cassava, and analysed for total $\mathrm{N}$, $\mathrm{K}$, organic matter and organic carbon. Planting was done in early August and weed was controlled manually. At maturity, four middle rows of soybean were harvested to determine seed yield. Cassava tuber yield, shoot dry matter and nutrient content $(\mathrm{N}$ and $\mathrm{K}$ ) were determined at 4, 8, and 12 months after planting.

\section{Nutrient Balance Estimation Method}

The quantities of nutrients ( $\mathrm{N}$ and $\mathrm{K}$ ) entering and leaving the field were estimated and the balances for $\mathrm{N}$ and $\mathrm{K}$ were calculated for the various treatments by aggregating input and output data for all the plots. This study examined only $\mathrm{N}$ and $\mathrm{K}$. The four input and four output processes are shown below:

Input 1 = mineral fertilizer applied:

1a, $\mathrm{N}_{0} \mathrm{~K}_{0}, \mathrm{~N}_{0} \mathrm{~K}_{50}, \mathrm{~N}_{45} \mathrm{~K}_{0}$ or $\mathrm{N}_{45} \mathrm{~K}_{50}$ $1 \mathrm{~b}$, initial soil $\mathrm{N}$ and $\mathrm{K}$

Input $\mathbf{2}=$ Crop residue:

Soybean stover and litter deposit quantities multiplied by $\mathrm{N}$ and $\mathrm{K}$ contents $(\mathrm{Kg})$

Input 3 = Atmospheric deposition:

$\mathrm{N}=0.14 \times$ Annual precipitation $(\mathrm{mm} / \mathrm{yr}$. $)$

$\mathrm{K}=0.09 \times$ Annual precipitation $(\mathrm{mm} / \mathrm{yr})$

Input 4 = (1) Non - Symboic N - Fixation = 2+(P-1.35) x 0.005. (2) Symboic NFixation:

Output 1 = Crop yield: $\mathrm{N}$ and $\mathrm{K}$ content of both cassava tuber and soybean grain multiplied by total yield of both
crops.(Kg ha $\left.{ }^{-1}\right)$

Output 2 = Crop Residue: Nutrient content of all the crop residues removed from the plot multiplied by total weight $\left(\mathrm{Kg} \mathrm{ha}^{-1}\right)$

Output 3 = Leaching: Leaching is determined by transfer function (Smaling, 1998)

Nitrogen $=(\mathrm{Ns}+\mathrm{Ni}) \times(0.021 \times \mathrm{P}-3.9 \times \mathrm{C}$

Where $\mathrm{Ns}=$ amount of mineralised $\mathrm{N}$ in the upper $20 \mathrm{~cm}$ of the soil.

$\mathrm{Ni}=$ amount of nitrogen applied

$\mathrm{P}=$ annual precipitation $(\mathrm{mm} / \mathrm{yr})$

$\mathrm{C}=$ clay content of the top soil $(\%)$

Potassium $=\left(\mathrm{Ke}+\mathrm{K}_{\mathrm{f}}(0.00029 \mathrm{X} \mathrm{p}+0.4)\right.$

Where: $\mathrm{Ke}=$ exchangeable $\mathrm{K}\left(\mathrm{cmol} \mathrm{Kg}{ }^{-1}\right)$

$\mathrm{K}_{\mathrm{f}}=$ amount $\mathrm{K}$ applied

$\mathrm{P}=$ annual precipitation,

$\mathrm{C}=$ clay content of the top soil $(\%)$

Output 4 =Gaseous losses: Consist of two parts:

Gaseous $N$ losses from the soil

Gaseous $N$ losses related with the

organic input

$=\left(\mathrm{Ns}+\mathrm{N}_{\mathrm{f}}\right) \times(-9.4+0.13) \times(\mathrm{C}+0.01 \times \mathrm{P})$

Where

$\mathrm{NS}=$ mineralised $\mathrm{N}$ in the root zone $\left(\mathrm{Kg} \mathrm{ha}^{-1}\right)$

$\mathrm{Nf}=\mathrm{N}$ applied

$\mathrm{C}=$ clay content $(\%)$ of the soil

$\mathrm{P}=$ mean annual precipitation $\left(\mathrm{mm} . \mathrm{yr}^{-1}\right.$ )

\section{RESULTS AND DISCUTION}

\section{Soil characteristics:}

The textural class of the soil before the treatments was a combination of sandy-clay and sandy-clay-loam. The $\mathrm{pH}$ at different soil depths (0$90 \mathrm{~cm}$ ) ranged between 4.0 and 4.2. Organic matter $(\mathrm{OM})$ at the top soil $(0-30 \mathrm{~cm})$ ranged from 1.43 to $1.74 \%$ followed by $30-60 \mathrm{~cm}$ depth (1.04-1.18\%) while $60-90 \mathrm{~cm}$ depth had the lowest organic matter (0.76-0.94\%). Similarly, the highest organic carbon $(0.81-0.84 \%)$ was obtained in the top soil $(0-30 \mathrm{~cm}$ depth), followed by $30-60 \mathrm{~cm}$ depth $(0.6-0.7 \%)$ while $60-90 \mathrm{~cm}$ depth had $0.44-0.54 \%$. Potassium content was similar in $0-60 \mathrm{~cm}$ depth in all the plots with a range of $0.11-0.13 \mathrm{meq} / 100 \mathrm{gK}$ while 60 $90 \mathrm{~cm}$ depth had a range of $0.08-0.09 \mathrm{meq} / 100 \mathrm{gK}$. Soil-N at 0-30 and $30-60 \mathrm{~cm}$ depths was similar and had the range of $0.041-0.050 \% \mathrm{~N}$, while $60-90 \mathrm{~cm}$ depth had the range of $0.032-0.038 \% \mathrm{~N}$.

Meteorological data during the years 2004, 2005 and 2006.

The average relative humidity was $74.78 \%$ for $2004,74.97 \%$ for 2005 and $75.55 \%$ for 2006 . Total annual rainfall for the three years, 2004, 2005 and 2006 were $1905.44 \mathrm{~mm} . \mathrm{yr}^{-1}$, 2062.83mm.yr ${ }^{-1}$ and 1982.32mm. $\mathrm{yr}^{-1}$, respectively. The distribution pattern of the rainfall for the three years was consistently bimodal, with heaviest rainfall in June and October each year. 
Umeh, S.I and Mbah, B.N.

\section{Nitrogen Balance}

The two varieties of cassava (Table 1) had negative $\mathrm{N}$ balances as sole crop at all fertilizer rates except $\mathrm{N}_{45} \mathrm{~K}_{50}$ which had positive $\mathrm{N}$ balance for NR 8230 $\left(+2.86 \mathrm{Kg} \mathrm{N} \mathrm{ha}^{-1}\right)$ and TMS $30572\left(+2.11 \mathrm{Kg} \mathrm{N} \mathrm{ha}^{-}\right.$ $\left.{ }^{1}\right)$. The negative nitrogen balances of the sole cassava at $\mathrm{N}_{0} \mathrm{~K}_{0}, \mathrm{~N}_{0} \mathrm{~K}_{50}$ and $\mathrm{N}_{45} \mathrm{~K}_{0}$ fertilizer rates revealed the low soil fertility of the experimental field and suggested the need for increased supply of nutrients to cassava especially, nitrogen. The result revealed also that intensive mono cropping without or with inadequate chemical fertilizer often results in greater losses of yield than gain. This was evidenced by the positive nitrogen balance obtained at $\mathrm{N}_{45} \mathrm{~K}_{50}$ fertilizer rate in sole cassava.

Sole soybean crops had positive nitrogen balances in all maturity groups and fertilizer rates. The varying ability of soybean varieties to fix $\mathrm{N}$ was shown in their $\mathrm{N}$ balances which ranged from $+1.88 \mathrm{Kg} \mathrm{N}^{-1}$ obtained from TGX 1869-17F to $+12.62 \mathrm{Kg} \mathrm{N}$ ha $^{-1}$ obtained from TGX 1894-3E. Nitrogen balances obtained from sole soybean showed that variety TGX 1894-3E had consistently higher $\mathrm{N}$ balance across all the fertilizer rates, while Samsoy -2 had consistently the lower $\mathrm{N}$ balance. The variations in the $\mathrm{N}$ balances across the cropping systems showed that legume nitrogen fixation vary according to variety, maturity class and management method and agree with Ladha and Reddy (2003) who indicated that the ability of legumes to fix atmospheric nitrogen differs widely within the lines. Nitrogen balances of sole soybean were significantly higher than their intercrops at all fertilizer rates.

\section{Varietals differences}

Intercrops of early maturing varieties of soybean had positive $\mathrm{N}$ balances at $\mathrm{N}_{0} \mathrm{~K}_{50}, \mathrm{~N}_{45} \mathrm{~K}_{0}$ and $\mathrm{N}_{45} \mathrm{~K}_{50}$ fertilizer rates. While their $\mathrm{N}$ balances at $\mathrm{N}_{0} \mathrm{~K}_{0}$ by all intercropping systems, were negative. TGX 1448-2E intercropped with TMS 30572 or NR 8320 gave higher $\mathrm{N}$ balance than Samsoy-2 intercropped with TMS 30572 or NR 8230 which was generally about $50 \%$ less than the $\mathrm{N}$ balance of the intercrops of TGX 1448-2E. Highest N balance $(+22.62 \mathrm{KgN}$ ha $^{-1}$ ) was obtained with $\mathrm{N}_{45} \mathrm{~K}_{50}$ by TGX 1448-2E intercropped with TMS 30572, while the lowest $\mathrm{N}$ balance $\left(-15.34 \mathrm{Kg} \mathrm{N}^{-1}\right.$ ) was obtained at $\mathrm{N}_{0} \mathrm{~K}_{0}$ intercropped with Samsoy-2.

For the medium maturing varieties, positive $\mathrm{N}$ balances within the intercrop were obtained at $\mathrm{N}_{0} \mathrm{~K}_{50}, \mathrm{~N}_{45} \mathrm{~K}_{0}$ and $\mathrm{N}_{45} \mathrm{~K}_{50}$ by all cropping systems, however, negative $\mathrm{N}$ balances were obtained at $\mathrm{N}_{0} \mathrm{~K}_{0}$ by all intercropping systems. Also, TGX 1894-3E intercropped with NR 8230 or TMS 30572, gave higher $\mathrm{N}$ balance than intercropping TGX $1805-31 \mathrm{~F}$ with either cassava variety at all fertilizer rates. Highest positive $\mathrm{N}$ balance $(+44.06$ $\mathrm{Kg} \mathrm{N} \mathrm{ha}^{-1}$ ) was obtained at $\mathrm{N}_{0} \mathrm{~K}_{50}$ by TGX 1894-3E intercropped with NR 8230 while the lowest $\mathrm{N}$ balance $\left(-9.43 \mathrm{Kg} \mathrm{N}^{-1}\right.$ ) was obtained at $\mathrm{N}_{0} \mathrm{~K}_{0}$ by TGX 1805-31F intercropped with TMS 30572. For the late maturing varieties, TGX 1889-12F intercropped with TMS 30572 or NR 8230 had similar $\mathrm{N}$ balances at $\mathrm{N}_{0} \mathrm{~K}_{50}$ and $\mathrm{N}_{45} \mathrm{~K}_{0}$ fertilizer rate. The highest $\mathrm{N}$ balance $\left(22.63 \mathrm{Kg} \mathrm{N}^{-1}\right)$ in the late maturing varieties was obtained at $\mathrm{N}_{45} \mathrm{~K}_{50}$ by TGX 1889-12F intercropped with NR 8230, while the lowest $\mathrm{N}$ balance $\left(-14.2 \mathrm{Kg} \mathrm{N} \mathrm{ha}^{-1}\right)$ was obtained at $\mathrm{N}_{0} \mathrm{~K}_{0}$ by TGX 1864-17F intercropped with $\mathrm{NR}$ 8320 .

Among all the intercropping systems by fertilizer rates, the medium maturing variety (TGX 1894-3E) intercropped with NR 8230 had the highest nitrogen balance $\left(+44.06 \mathrm{Kg} \quad \mathrm{N} \quad \mathrm{ha}^{-1}\right)$ This variety intercropped with TMS 30572 also had the second highest nitrogen balance $\left(+41.11 \mathrm{Kg} \mathrm{N} \mathrm{ha}^{-1}\right)$ at $\mathrm{N}_{0} \mathrm{~K}_{50}$ fertilizer rate. This observation showed that nitrogen input from BNF under intercropping with legumes significantly reduced the requirement of chemical nitrogen fertilizer. Bruno et al. (2003) observed that the real benefit of biological nitrogen fixation (BNF) to the cropping system depend on the proportion of plant nitrogen derived from BNF. Our result agrees with report of Aggarwal et al. (2002) who reported that when $\mathrm{N}$ from legumes becomes available for uptake by the non-legume intercrop, non-legume yield may increase above the level of the monocrop. 
Table 1: Effect of Fertilizer rate and Cropping System on Nitrogen (N) Balance (Kg N ha $^{1}$ )

\begin{tabular}{|c|c|c|c|c|c|}
\hline & \multirow[t]{2}{*}{ Cropping systems (C) } & \multicolumn{4}{|c|}{ Fertilizer rates $(\mathrm{F})$} \\
\hline & & $\mathrm{N}_{0} \mathrm{~K}_{0}$ & $\mathrm{~N}_{0} \mathrm{~K}_{50}$ & $\mathrm{~N}_{45} \mathrm{~K}_{0}$ & $\mathrm{~N}_{45} \mathrm{~K}_{50}$ \\
\hline \multirow{8}{*}{$\begin{array}{l}\text { Early } \\
\text { maturing }\end{array}$} & Cassava NR 8230 Sole & -27.33 & -11.33 & -4.12 & +2.86 \\
\hline & Cassava TMS 30572 Sole & -26.96 & -9.45 & -3.88 & +2.11 \\
\hline & TGX 1448-2E Sole & +6.90 & $+\mathrm{i} 0.6$ & $+\mathrm{I} 6.42$ & +24.81 \\
\hline & TGX 1448-2E/NR 8230 & -8.75 & +8.90 & +15.0 & +22.51 \\
\hline & TGX 1448-2E/TMS 30572 & -14.22 & +9.27 & +13.32 & +22.62 \\
\hline & Samsoy-2 Sole & +2.33 & +3.02 & +10.14 & +12.22 \\
\hline & Samsoy-2/NR 8230 & -15.34 & +0.37 & +7.79 & +10.33 \\
\hline & Samsoy-2/TMS 30572 & -7.07 & +0.49 & +8.51 & +14.81 \\
\hline \multirow{6}{*}{$\begin{array}{l}\text { Medium } \\
\text { maturing }\end{array}$} & TGX 1894-3E Sole & +12.62 & +62.85 & +42.45 & +46.81 \\
\hline & TGX 1894-3E/NR 8230 & -4.80 & +44.06 & +25.00 & +25.93 \\
\hline & TGX 1894-3E/TMS 30572 & -6.81 & +41.11 & +23.69 & +23.96 \\
\hline & TGX 1805-31F Sole & +4.37 & +8.62 & +18.22 & +24.33 \\
\hline & TGX 1805-31F/NR 8230 & -8.95 & +0.61 & +12.74 & +16.47 \\
\hline & TGX 180531F/TMS 30572 & -9.43 & +0.94 & +12.88 & +17.26 \\
\hline \multirow{7}{*}{$\begin{array}{l}\text { Late } \\
\text { maturing }\end{array}$} & TGX 1889-12F Sole & +7.66 & +28.61 & +19.86 & +19.55 \\
\hline & TGX 1889-12F/NR 8230 & -10.91 & +19.03 & +15.72 & +22.63 \\
\hline & TGX 1889-12F/TMS 30572 & -12.01 & +19.92 & +13.84 & +21.52 \\
\hline & TGX 1864-17F Sole & +1.88 & +22.64 & +18.62 & +22.33 \\
\hline & TGX1864-17F/NR 8230 & -14.20 & +11.7 & +14.2 & +20.71 \\
\hline & TGX186417F/TMS 30572 & -7.90 & +11.4 & +11.1 & +20.75 \\
\hline & $\mathrm{LSD}_{0.05}$ & 0.52 & 0.73 & 2.12 & 0.33 \\
\hline
\end{tabular}

Key: $\quad \mathrm{N}_{0} \mathrm{~K}_{0}=0 \mathrm{~kg} \mathrm{~N} \mathrm{ha}^{-1}$ and $0 \mathrm{~kg} \mathrm{~K} \mathrm{ha}^{-1}$

$\mathrm{N}_{0} \mathrm{~K}_{50}=0 \mathrm{~kg} \mathrm{~N} \mathrm{ha}^{-1}$ and $50 \mathrm{~kg} \mathrm{~K} \mathrm{ha}^{-1}$

$\mathrm{N}_{45} \mathrm{~K}_{0}=45 \mathrm{~kg} \mathrm{~N} \mathrm{ha}^{-1}$ and $0 \mathrm{~kg} \mathrm{~K} \mathrm{ha}^{-1}$

$\mathrm{N}_{45} \mathrm{~K}_{50}=45 \mathrm{~kg} \mathrm{~N}^{-1}$ and $50 \mathrm{~kg} \mathrm{~K}$ ha

Table 2: Effects of Fertilizer Rate and Cropping System on Potassium (K) Balance (Kg ha $^{-1}$ )

\begin{tabular}{|c|c|c|c|c|c|}
\hline & & Fertilizer & Rates $(\mathrm{F})$ & & \\
\hline & Cropping systems (C) & $\mathrm{N}_{0} \mathrm{~K}_{0}$ & $\mathrm{~N}_{0} \mathrm{~K}_{50}$ & $\mathrm{~N}_{45} \mathrm{~K}_{0}$ & $\mathrm{~N}_{45} \mathrm{~K}_{50}$ \\
\hline \multirow[t]{4}{*}{ Cassava } & Sole NR 8230 & -12.4 & +10.75 & -6.4 & +12.23 \\
\hline & Sole TMS 30572 & -10.6 & +9.6 & -5.6 & +13.22 \\
\hline & TGX 1448-2E Sole & +0.35 & +30.88 & +1.45 & +44.62 \\
\hline & TGX 1448-2E/NR 8230 & -3.62 & +26.26 & -6.24 & +31.05 \\
\hline \multirow{5}{*}{$\begin{array}{l}\text { Early } \\
\text { Maturing }\end{array}$} & TGX 1448-2E/TMS 30572 & -3.10 & +26.70 & -1.40 & +33.20 \\
\hline & Samsoy-2 Sole & +3.86 & +52.6 & +8.86 & +54.33 \\
\hline & Samsoy-2/NR 8230 & -2.10 & +44.29 & -2.90 & +46.77 \\
\hline & Samsoy-2/TMS 30572 & +2.03 & +49.82 & +6.19 & +46.54 \\
\hline & TGX 1889-3E Sole & +8.24 & +88.24 & +7.65 & +85.26 \\
\hline \multirow{6}{*}{$\begin{array}{l}\text { Medium } \\
\text { Maturing }\end{array}$} & TGX 1894-3E/NR 8230 & +4.01 & +72.70 & +5.74 & +76.30 \\
\hline & TGX 1894-3E/TMS 30572 & +4.37 & +72.40 & +4.40 & +78.50 \\
\hline & TGX 1805-31 Sole & +18.25 & +64.26 & +10.21 & +62.33 \\
\hline & TGX 1805-31F/NR 8230 & +10.90 & +58.85 & +8.00 & +58.30 \\
\hline & TGX 1805-31F/TMS 30572 & +12.70 & +51.96 & +8.90 & +59.88 \\
\hline & TGX 1889-12F Sole & +6.28 & +52.11 & +4.26 & +57.31 \\
\hline \multirow{6}{*}{$\begin{array}{l}\text { Late } \\
\text { Maturing }\end{array}$} & TGX 1889-12F/NR 8230 & -4.63 & +43.73 & +2.95 & +44.77 \\
\hline & TGX 1889-12F/TMS 30572 & -7.61 & +30.00 & -5.90 & +37.74 \\
\hline & TGX 1864-17F Sole & +4.32 & +58.22 & +8.96 & +61.33 \\
\hline & TGX 1864-17F/NR 8230 & -2.82 & +45.64 & -6.66 & +44.79 \\
\hline & TGX 1864-17F/T 30572 & +2.00 & +51.93 & +3.83 & +53.72 \\
\hline & $\mathrm{LSD}_{0.05}$ & 0.4 & 1.2 & 0.42 & 1.3 \\
\hline
\end{tabular}

Key: $\quad \mathrm{N}_{0} \mathrm{~K}_{0}=0 \mathrm{Kg} \mathrm{N} \mathrm{ha}^{-1}$ and $0 \mathrm{Kg} \mathrm{K}$ ha

$\mathrm{N}_{0} \mathrm{~K}_{50}=0 \mathrm{Kg} \mathrm{N} \mathrm{ha}^{-1}$ and $50 \mathrm{Kg} \mathrm{Kha}^{-1}$

$\mathrm{N}_{45} \mathrm{~K}_{0}=45 \mathrm{Kg} \mathrm{N} \mathrm{ha}^{-1}$ and $0 \mathrm{Kg} \mathrm{K} \mathrm{ha}{ }^{-1}$

$\mathrm{N}_{45} \mathrm{~K}_{50}=45 \mathrm{Kg} \mathrm{N}^{-1} \mathrm{a}^{-1}$ and $50 \mathrm{Kg} \mathrm{K} \mathrm{ha}^{-1}$ 
In all the maturity groups and varieties, there were varietal differences in nitrogen balances. The positive $\mathrm{N}$ balances obtained at the application of only potassium fertilizer $\left(\mathrm{N}_{0} \mathrm{~K}_{50}\right)$ in intercrop systems showed that potassium plays significant role in nitrogen metabolism and agrees with the report of Rains, 1976 who observed the role of potassium as a cofactor in the nutrient metabolism. Our result suggests also that both nitrogen and potassium were limiting for cassava growth in the derived Savannah zone (Nsukka). When adequate K was supplied through mineral fertilization and nitrogen made available through biological nitrogen fixation, the nutrient balance improved. However, the negative $\mathrm{N}$ balance which was obtained at $\mathrm{N}_{0} \mathrm{~K}_{0}$ suggest low nutrient status of the soil for both $\mathrm{N}$ and $\mathrm{K}$. Generally, the nonvarietal effect of cassava in the cropping system showed that the two varieties of cassava are suitable for the intercrop. A sustainable cropping system could be obtained by the integrated use of potassium fertilizer and BNF. From our results, intercrop of TGX 1889-3E by $\mathrm{N}_{0} \mathrm{~K}_{50}$ with either cassava varieties, gave the highest $\mathrm{N}$ balance and from their performance, the most sustainable cropping system.

\section{Potassium Balance}

Sole cassava varieties (NR 8230 and TMS 30572) had negative K-balances at $\mathrm{N}_{0} \mathrm{~K}_{0}$ and $\mathrm{N}_{45} \mathrm{~K}_{0}$ fertilizer rates (Table 2) and positive $\mathrm{K}$ balances at $\mathrm{N}_{0} \mathrm{~K}_{50}$ and $\mathrm{N}_{45} \mathrm{~K}_{50}$ fertilizer rates. Negative $\mathrm{K}$ balances obtained at $\mathrm{N}_{0} \mathrm{~K}_{0}$ and $\mathrm{N}_{45} \mathrm{~K}_{0}$ showed that potassium was limiting in the soil for cassava crop production, whereas addition of potassium $\left(\mathrm{N}_{0} \mathrm{~K}_{50}\right.$ and $\left.\mathrm{N}_{45} \mathrm{~K}_{50}\right)$, resulted in the positive $\mathrm{K}$ balances (+9.6 to $+13.32 \mathrm{Kg} \mathrm{ha}^{-1}$ ). This result further suggests that $K$ is one of the nutrients limiting for cassava production in the Southeast Savannah zone. The non- significant differences in the potassium balances of the two cassava varieties by fertilizer rates further showed that variety did not affect potassium uptake in cassava. Potassium balances for both sole cassava varieties were significantly lower than $\mathrm{K}$ balances at intercrop within each fertilizer rate indicating that intercropped soybean crop contributed much to the potassium balance of the cropping system.

Sole soybean crops had positive potassium balances in all cropping systems and fertilizer rates. Potassium balances at sole soybean were significantly higher than the intercrops by all soybean varieties and fertilizer rates. Positive potassium balances obtained in $\mathrm{N}_{0} \mathrm{~K}_{0}$ and $\mathrm{N}_{45} \mathrm{~K}_{0}$ by cropping systems showed that initial soil $\mathrm{K}$ may have been adequate for soybean growth, though maximum grain yield was not attained at these fertilizer rates $\left(\mathrm{N}_{45} \mathrm{~K}_{0}\right.$ and $\left.\mathrm{N}_{0} \mathrm{~K}_{0}\right)$. This observation points out more clearly the varietal effect of soybean on accumulation and utilization of potassium at both sole and intercrop systems. Highest potassium balance of sole soybean $\left(+88.24 \mathrm{Kg} \mathrm{K} \mathrm{ha}^{-1}\right)$ was obtained at TGX $1894-3 \mathrm{E}$ system by $\mathrm{N}_{0} \mathrm{~K}_{50}$, whereas the lowest $\left(+0.35 \mathrm{Kg} \mathrm{ha}^{-1}\right)$ was obtained at TGX $1448-2 \mathrm{E}$ by $\mathrm{N}_{0} \mathrm{~K}_{0}$. Sole soybean on the other hand showed significant effect of the varieties on $\mathrm{K}$ balance. When there was no fertilizer application $\left(\mathrm{N}_{0} \mathrm{~K}_{0}\right), \quad \mathrm{K}$ balance varied significantly with soybean varieties and maturity groups by fertilizer rates and ranged from +0.35 Kg K ha- ${ }^{1}$ obtained from TGX 1448-2E (early maturing variety) to $+18.25 \mathrm{Kg} \mathrm{K}$ ha- $^{1}$ (medium maturing variety). The overall result supports the assumption that soybean may play a role on the metabolic processes of potassium in the cropping system by influencing the release of potassium from the soil inert potassium reserve. Defoer et al., (2000) noted that when plants take up potassium, the equilibrium between the dynamic and inert reserve is temporally disrupted, some of the exchangeable potassium must then be released into the soil solution to reestablish this equilibrium..

Intercrops of early maturing varieties gave positive $\mathrm{K}$ balances with $\mathrm{N}_{0} \mathrm{~K}_{50}$ and $\mathrm{N}_{45} \mathrm{~K}_{50}$ fertilizer rates and negative potassium balances at $\mathrm{N}_{45} \mathrm{~K}_{0}$ by $\mathrm{TGX} 1448-2 \mathrm{E}$ intercropped with either variety of cassava (-6.24 and $-1.40 \mathrm{Kg} \mathrm{K}$ ha $^{-1}$, respectively), $\mathrm{N}_{45} \mathrm{~K}_{0}$ by Samsoy-2 intercropped with NR 8230 (-2.9 $\left.\mathrm{Kg} \mathrm{K} \mathrm{ha}^{-1}\right)$ and at $\mathrm{N}_{0} \mathrm{~K}_{0}$ by $\mathrm{TGX} 1448-2 \mathrm{E}$ intercropped with either variety of cassava (-3.62 and $-3.10 \mathrm{Kg} \mathrm{K}$ $\mathrm{ha}^{-1}$ ) and Samsoy-2 intercropped with NR 8230 $\left(-2.10 \mathrm{Kg} \mathrm{K} \mathrm{ha}^{-1}\right)$. There was also positive $\mathrm{K}$ balance $\left(+6.19,+2.03 \mathrm{Kg} \mathrm{K} \mathrm{ha}^{-1}\right)$ with Samsoy-2 intercropped with TMS 30572 at $\mathrm{N}_{45} \mathrm{~K}_{0}$ and $\mathrm{N}_{0} \mathrm{~K}_{0}$ fertilizer rates, respectively. The highest positive potassium balance of $+49.82 \mathrm{Kg} \mathrm{K}^{-1}$ was obtained with Samsoy- 2 by $\mathrm{N}_{0} \mathrm{~K}_{50}$ intercropped with TMS 30572. Intercropping TGX 1448-2E with TMS 30572 gave higher K balance than intercropping with NR 8230 at all fertilizer rates. Generally, there were varying K balances which were not due to cassava varieties but due to soybean varieties.

For the intercrops of medium maturing varieties by fertilizer rates, $\mathrm{K}$ balances of each variety did not always differ significantly confirming that cassava varieties did not affect $\mathrm{K}$ balances. Highest positive $\mathrm{K}$ balance $(+78.50 \mathrm{Kg}$ $\mathrm{K} \mathrm{ha}^{-1}$ ) was obtained at $\mathrm{N}_{45} \mathrm{~K}_{50}$ by TGX $1894-3 \mathrm{E}$ intercropped with TMS 30572 cassava variety.

Late maturing variety, TGX 1864-17F intercropped with TMS 30572 at $\mathrm{N}_{45} \mathrm{~K}_{50}$ gave the highest positive $\mathrm{K}$ balance $\left(53.72 \mathrm{Kg} \mathrm{K} \mathrm{ha}^{-1}\right.$ ) among the intercrops. Potassium balances at $\mathrm{N}_{0} \mathrm{~K}_{50}$ and $\mathrm{N}_{45} \mathrm{~K}_{50}$ at all cropping systems were 
positive, whereas potassium balances at $\mathrm{N}_{0} \mathrm{~K}_{0}$ and $\mathrm{N}_{45} \mathrm{~K}_{0}$ were negative except TGX 1889-12F intercropped with NR 8230 at $\mathrm{N}_{45} \mathrm{~K}_{0} \quad(+2.95 \mathrm{Kg}$ $\mathrm{K} \mathrm{ha}^{-1}$ ) and TGX 1864-17F intercropped with TMS 30572 which have positive $\mathrm{K}$ balances at all fertilizer rates. Intercropping TGX 1889-12F with TMS 30572 at $\mathrm{N}_{0} \mathrm{~K}_{0}$ gave the lowest potassium balance of $-7.61 \mathrm{Kg} \mathrm{K} \mathrm{ha}^{-1}$

Our results agree with the findings of Awonaike et al. (1992) who reported that the amount of nitrogen fixed by soybean depends on the soybean variety, maturity class and type of crop management method. Our results further stressed that the advantages of legume intercrop with non-legume or non-fixing plant may not be fully realised without understanding the limiting factors for biological nitrogen fixation in an intercropping system The positive $\mathrm{N}$ balances obtained at the application of only potassium fertilizer $\left(\mathrm{N}_{0} \mathrm{~K}_{50}\right)$ in intercrop systems showed that potassium plays significant role in nitrogen metabolism and agree with the report of Rains, 1976 who observed the role of potassium as a cofactor in the nutrient metabolism. Increasing the $\mathrm{K}^{+}$available to the plants $\left(\mathrm{N}_{0} \mathrm{~K}_{50}\right.$ and $\mathrm{N}_{45} \mathrm{~K}_{50}$ fertilizer rates) caused significant increase in the soil nutrient balance more than where there was no K. Tarrace and Gieiger (1982) made similar observation and reported that increased $\mathrm{K}^{+}$ nutrition on sugar beet plants promoted the translocation of products of photosynthesis, affect the metabolic conversion of sucrose in the sink tissues and resulted in net carbon increase and $\mathrm{C} / \mathrm{N}$ ratio.

\section{CONCLUSION}

In Nigeria, cassava is an important food crop, nitrogen and potassium nutrient elements are the key inputs. Most of these elements come from soil inert reserve, chemical sources and biological nitrogen fixation. As soil organic matter got continually lost through plant removal, leaching, denitrification and volatilization, BNF helps to replenish the soil nitrogen pool which results in positive $\mathrm{N}$ balance. When adequate $\mathrm{K}$ was supplied through mineral fertilization $\left(\mathrm{N}_{0} \mathrm{~K}_{50}\right)$, the nutrient balances improved. However, the negative $\mathrm{N}$ balances obtained at $\mathrm{N}_{0} \mathrm{~K}_{0}$ suggest low nutrient status of the soil for both $\mathrm{N}$ and $\mathrm{K}$. Generally, the non-varietal effect of cassava in the cropping system showed that the two varieties of cassava are suitable for the intercrop. The variations in the $\mathrm{N}$ balances across the cropping systems showed that legume nitrogen fixation vary according to variety, maturity class and management method. From our results, intercrop of medium maturity of soybean TGX 1889-3E with either cassava varieties and on application of $50 \mathrm{Kg} \mathrm{K} \mathrm{ha}^{-1}\left(\mathrm{~N}_{0} \mathrm{~K}_{50}\right)$ gave the highest $\mathrm{N}$ and
$\mathrm{K}$ balances and from their performance, the most sustainable cropping system in the derived Savannah zone of South East of Nigeria.

\section{REFERENCE}

Aggarwal, P.K., Garrity, D.P., Liboon, S.P. and Morris, R.A. (2002). Resource use and plant interaction in rice-mungbean intercrop. Agron. J. 84: 71-78.

Awonaike, K.O., Handedrson, G and Kiunaraisinghe J.S., (1992). Biological nitrogen fixation of Gliricidia septum/Ryzobium symbiosis as influced by plant genotype, bacteria strain and their interaction. Tropical Agriculture 69(4), 381-385.

Bruno, J.R.A., Robart, M.B. and Urguiaga, S. (2003) The Success of BNF in soybean in Brazil. Plant and Soil 252: 1-9.

Dechert, G., Veldkamp E. and Brumme, R. (2004). Are partial nutrient balances suitable to evaluate sustainability of land use system? Results from a case study in central Sulawesi, Indonesia. Nutrient cycling in Agro ecosystem 72: 201-212.

Defoer, T., Budelman, A., Toulmin., and Carter, S.E. (2000) Building Common Knowledge. Participatory learning and action Research (part 1). In: Defoer, T. Budelman A (eds). Managing Soil Fertility in the Tropics. A Resource Guide for participatory learning and action research. Amsterdam. The Netherlands: Royal Tropical Institute.

FAO (Food and Agriculture Organisation of the United Nations), (2003). Scaling soil nutrient balances, J.P. Lesscher, R.D. Asiamah, P. Gicheru, S. Kante, J.J. Stroovogel and Smailing E.M.A. Rome.

Howeler, R.H. (2001) Nutrient inputs and losses in cassava - based Cropping System Example from Vietnam and Thailand. International workshop on Nutrient Balance for sustainable Agricultural Production and Natural Resource management in Southeast Asia, Bangkok, Thailand, 20-22 February, 2001.

Howeler, R.H. and Candavid, L.F. (1983) Accumulation and Distribution of Dry matter and Nutrients during a 12 month Growth cycle of Cassava. Field crops Research. 7, 123-139

Ladha, J.K. and Reddy, P.M. (2003) Nitrogen fixation in rice systems: State of knowledge and feature prospects. Plant and Soil, 252: 151-167

Ledgard, S.F. (2001). Nitrogen cycling in low input legume-based agriculture, with emphasis on legume/grass pastures. Plant and Soil 228: 43-59 
Rains, D. W. (1976) Mineral metabolism In: J. Bonner, J. Varner (eds.). Plant Biochemistry. Academic Press, New York, pp 569-573

Smaling, E.M.A. (1998). Nutrient balances as indicators of productivity and sustainability in Sub-saharan African Agriculture. Special issue Ag. Ecosys. Env., 7

Stoorvogel, J.J., Smalling, E.M.A. (1990). Assessment of soil nutrient depletion in Sub-Sahvana Africa 1983-2000. Report 28. Wageningen. The Netherlands, Win and Stari
Terrance, R. C. and Geiger, R. D. (1982) Potassium Nutrition and Translocation in ugar beet. Plant physiology, 70: 169172.

Umeh S.I. (2002). Effect of nitrogen fertilization and legume nitrogen contribution on Growth and yield of Cassava (Manihot esculenta Crantz) and soybean (Glycine max. (L). Merril) Intercrops. Msc. Thesis. University of Nigeria, Nsukka.120pp. 